Anaesthesist 2013 $\cdot$ 62:869-871

DOI 10.1007/s00101-013-2268-5

Online publiziert: 23. November 2013

c) Springer-Verlag Berlin Heidelberg 2013
B. Zwißler ${ }^{1} \cdot$ R. Rossaint ${ }^{2}$

${ }^{1}$ Klinik für Anaesthesiologie, LMU, Klinikum der Universität München

2 Klinik für Anästhesiologie, RWTH Aachen

\title{
Entscheidung der European Medicines Agency zur Hydroxyäthylstärke
}

\author{
Ein wichtiger Schritt in Richtung \\ Therapie- und Rechtssicherheit
}

Am Freitag, den 25.10.2013, veröffentlichte die Europäische Arzneimittelbehörde (European Medicines Agency, EMA) ihre neue Empfehlung zur Verwendung von Hydoxyäthylstärke(HES)haltigen Infusionslösungen ([1], englischer Volltext s. Anhang). Diese Empfehlung (EMA/640658/2013) beruht auf einer kurz zuvor abgeschlossenen Bewertung des „Pharmacovigilance Risk Assessment Committee“ (PRAC) der EMA und löst eine Stellungnahme des PRAC aus dem Juni dieses Jahres ab.

Hydoxyäthylstärke darf demnach auch weiterhin bei Patienten mit Sepsis oder Verbrennungen und anderweitig kritisch kranken Patienten nicht mehr angewendet werden („must no longer be used“). Dagegen ist eine Anwendung (wieder) möglich bei Patienten mit einer durch einen akuten Blutverlust hervorgerufenen Hypovolämie, die durch die Gabe von kristalloiden Infusionslösungen allein nicht suffizient behandelt werden kann. Der Gebrauch sollte auf $24 \mathrm{~h}$ beschränkt und die Nierenfunktion der Patienten im Anschluss überwacht werden. Zu Art und Zeitraum der Überwachung der Nierenfunktion erfolgten in der Stellungnahme der EMA keine näheren Angaben. Zudem werden die Arzneimittelhersteller aufgefordert, die Fachinformationen entsprechend zu ändern und den Gebrauch von HES im Rahmen elektiver chirurgischer Eingriffe sowie bei Traumapatienten durch Studien weiterzuevaluieren.
Diese Empfehlung der EMA wird nun an die Europäische Kommission weitergeleitet mit dem Ziel, eine EU-weit geltende und rechtlich verbindliche Entscheidung herbeizuführen. Da wenig Zweifel daran bestehen, dass die Europäische Kommission die Empfehlung der EMA in der vorliegenden Form übernehmen wird, scheint die Diskussion zum Thema HES durch das aktuelle Votum der Europäischen Aufsichtsbehörde zumindest bis auf Weiteres zum Abschluss gekommen zu sein.

Dies ist aus Sicht des klinisch tätigen Arztes aus zwei Gründen zu begrüßen: Zum einen beendet die Entscheidung der EMA eine mehrere Monate anhaltende Zeit der Therapie-, aber auch Rechtsunsicherheit. So war völlig unklar, ob und wenn ja, welche rechtlichen Konsequenzen derjenige zu befürchten hatte, der HES im Rahmen der ärztlichen Therapiefreiheit, aber eben gegen die initiale, von einer weiteren Verwendung von HES grundsätzlich abratenden Empfehlung der EMA bei Patienten einsetzt. Zum anderen war unklar, ob verfügbare Alternativen zu HES die Therapiesicherheit tatsächlich verbessern würden [2].

Auch wenn die neue Empfehlung der EMA diese beiden Fragen letztlich nicht beantwortet, ist die Ausgangslage nun deutlich klarer und trägt - daher ist die Entscheidung ebenfalls hilfreich - v. a. der Tatsache Rechnung, dass die RisikoNutzen-Abwägung für den Einsatz von
Medikamenten selten eindimensional (schwarz-weiß) ist, sondern wesentlich von der Konstellation der Anwendung abhängt: hier der Patient auf der Intensivstation, der in der Regel eng überwacht ist, über ausreichende venöse Zugänge verfügt und meist durch Flüssigkeitsverluste (Fieber) oder eine relative Hypovolämie infolge eingeschränkter vaskulärer Barrierefunktion oder Vasoplegie bedroht ist. Dort der Patient mit Polytrauma oder während eines komplexen chirurgischen Eingriffs, bei dem es innerhalb kürzester Zeit aufgrund von Blutverlusten zur absoluten Hypovolämie sowie zum Kreislaufschock kommt und bei dem eine rasche Kreislaufstabilisierung in akzeptabler Zeit durch Kristalloide allein rein physikalisch (limitierte Infusionsmenge pro Zeit, eingeschränkte Volumenwirksamkeit) scheitert. Wirkungen und Nebenwirkungen relativieren sich unter diesen Bedingungen und müssen zu einer individuellen RisikoNutzen-Abwägung führen.

Die teilweise emotionale und vielfach kontroverse Diskussion der letzten Monate hatte - bei aller damit verbundenen Unsicherheit - jedoch auch etwas Gutes. Sie schärfte die Sinne im Hinblick auf ein Medikament, das in der Vergangenheit sicherlich nicht selten zu unreflektiert, in der falschen Dosierung, beim falschen Patienten und unter Vernachlässigung der Kontraindikationen eingesetzt worden war. Die Indikationen sind nun ebenso klar wie die Kontraindikationen, 
und die empfohlene zeitliche Begrenzung der Anwendung auf $24 \mathrm{~h}$ trägt der verbliebenen Indikation - dem akuten schweren Blutverlust - Rechnung. Am wenigsten hilfreich für die Praxis erscheint der Hinweis der EMA auf eine Überwachung der Nierenfunktion nach Gabe von HES, da wirklich befriedigende und praxistaugliche Messparameter für die Integrität der Nieren bis heute nicht verfügbar sind und unklar ist, wer die Überwachung wann durchführen soll. Dies war wahrscheinlich auch der Grund dafür, dass die EMA in diesem Zusammenhang von einer zwingenden Vorgabe zugunsten einer unverbindlicheren „Sollte“-Empfehlung („kidney function should be monitored ...") abgesehen hat.

Der anwendende Arzt ist nun gehalten, die durch die EMA vorgegebenen Anwendungsbeschränkungen zu beherzigen und den indikationsgemäßen Gebrauch von HES sicherzustellen. Fast noch wichtiger jedoch: Die forschende pharmazeutische Industrie ist eindeutig aufgefordert, die dringend benötigten Studien auf den Weg zu bringen, die es uns ermöglichen, die nach wie vor bestehenden beträchtlichen Wissenslücken im Bereich der Infusionstherapie zu schließen.

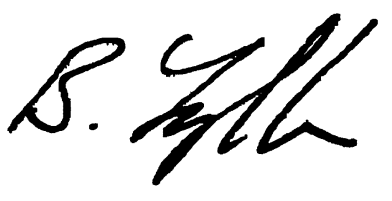

Bernhard Zwißler

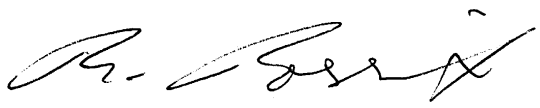

Rolf Rossaint

\section{Korrespondenzadresse}

Prof. Dr. B. Zwißler

Klinik für Anaesthesiologie, LMU, Klinikum der Universität München

Marchioninistr. 15, 81377 München

Bernhard.Zwissler@med.uni-muenchen.de

\section{Einhaltung ethischer Richtlinien}

Interessenkonflikt. B. Zwißler und R. Rossaint geben an, dass kein Interessenkonflikt besteht.

\section{Literatur}

1. European Medicines Agency (2013) Hydroxyethylstarch solutions (HES) should no longer be used in patients with sepsis or burn injuries or in critically ill patients - CMDh endorses PRAC recommendations. http://www.ema.europa.eu/ema

2. Rehm M (2013) Anwendungsbeschränkung für Hydroxyäthylstärke. Hintergründe und alternative Konzepte. Anaesthesist 62:644-655. DOI 10.1007/ s00101-013-2220-8

\section{Anhang}

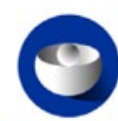

EUROPEAN MEDICINES AGENCY SCIENCE MEDICINES HEALTH

\section{European Medicines Agency}

25 October 2013 - EMA/640658/2013

Hydroxyethyl-starch solutions (HES) should no longer be used in patients with sepsis or burn injuries or in critically ill patients - CMDh endorses PRAC recommendations

\section{HES will be available in restricted patient populations}

The Coordination Group for Mutual Recognition and Decentralised Procedures - Human (CMDh) has endorsed by majority the recommendations of the European Medicines Agency's Pharmacovigilance Risk Assessment Committee (PRAC), which concluded that HES solutions must no longer be used to treat patients with sepsis (bacterial infection in the blood) or burn injuries or critically ill patients because of an increased risk of kidney injury and mortality.

The CMDh also agreed with the PRAC recommendation that HES solutions may continue to be used in patients to treat hypovolaemia (low blood volume) caused by acute (sudden) blood loss, where treatment with alternative infusions solutions known as ,crystalloids' alone are not considered to be sufficient. In order to minimise potential risks in these patients, HES solutions should not be used for more than 24 hours and patients' kidney function should be monitored after HES administration. In addition to updating the product information, further studies should be carried out on the use of these medicines in elective surgery and trauma patients.

The review of HES solutions was carried out by the PRAC following the publication of studies showing an increased risk of mortality in patients with sepsis ${ }^{1,2}$ and an increased risk of kidney injury requiring dialysis in critically ill patients ${ }^{1,2,3}$ following treatment with HES solutions.

As the CMDh position has been adopted by majority vote, it will now be sent to the European Commission, which will take a final legally binding decision that will be valid throughout the European Union (EU).

\section{Information for patients}

- Because of the risk of kidney injury and mortality, HES solutions must no longer be used in patients with sepsis (bacterial infection in the blood) or burn injuries or critically ill patients.

- HES solutions may continue to be used to treat hypovolaemia (low blood volume) caused by acute (sudden) blood loss. However, the doctor should monitor the patient's kidney function after HES administration.

- Patients who have any questions or concerns should speak to the treating doctor, pharmacist or nurse.

\section{Information for healthcare professionals}

- Because of the risk of kidney injury and mortality, HES solutions must no longer be used in patients with sepsis, burn injuries or critically ill patients.

- HES solutions should only be used for the treatment of hypovolaemia due to acute blood loss when crystalloids alone are not considered sufficient.

- There is a lack of robust long-term safety data in patients undergoing surgical procedures and in patients with trauma. The expected benefit of treatment should be carefully weighed against the uncertainties with regard to long-term safety and other available treatment options should be considered. Additional studies will be performed with HES solutions in patients with trauma and in elective surgery. 
- HES solutions should be used at the lowest effective dose for the shortest period of time. Treatment should be guided by continuous haemodynamic monitoring so that the infusion is stopped as soon as appropriate haemodynamic goals have been achieved.

- HES solutions are now contraindicated in patients with renal impairment or renal replacement therapy. The use of HES must be discontinued at the first sign of renal injury. An increased need for renal replacement therapy has been reported up to 90 days after HES administration. Patients' kidney function should be monitored after HES administration.

- HES solutions are contraindicated in severe coagulopathy. HES solutions should be discontinued at the first sign of coagulopathy. Blood coagulation parameters should be monitored carefully in case of repeated administration.

These recommendations are based on a review of all available safety and efficacy data, including recent data ${ }^{4,5,6}$ from clinical studies, meta-analyses and post-marketing experience.

Healthcare professionals will be informed in writing of the outcome of the review and the changes to the use of HES solutions.

\section{More about the medicine}

Infusion solutions containing HES are frequently used for volume replacement and belong to the class known as colloids. There are two main types of medicines used for volume replacement: crystalloids and colloids. Colloids contain large molecules such as starch, whereas crystalloids, such as saline (salt) solutions or Ringer's acetate, contain smaller molecules.

In the EU, HES-containing solutions for infusion have been approved via national procedures and are available in all Member States under various trade names.

\section{More about the procedures}

A review of HES solutions for infusion was initiated on 29 November 2012 at the request of the German medicines agency, under Article 31 of Directive 2001/83/ EC. This review, which had been carried out by the Pharmacovigilance Risk Assessment Committee (PRAC), concluded on 13 June 2013, but some of the marketing authorisation holders requested a reexamination.

While the re-examination was ongoing, some Member States decided to suspend or limit the marketing or use of these medicines in their territories. In accordance with EU legislation, this type of action required that an EU review procedure be carried out. Consequently, on 27 June 2013, the UK triggered an EU review of HES solutions under Article 107i of Directive 2001/83/EC. This review procedure ran in parallel with the re-examination of the PRAC's June 2013 recommendation and both procedures were finalised on 10 October 2013. For the re-examination procedure the PRAC confirmed its previous position. However, new evidence was considered in the parallel Article $107 \mathrm{i}$ procedure and this was the basis for the PRAC's final recommendation on the use of HES solutions.

As HES-containing solutions for infusion are all authorised nationally, the PRAC recommendations were forwarded to the Co-ordination Group for Mutual Recognition and Decentralised Procedures - Human (CMDh), which adopted a final position. The $\mathrm{CMDh}$, a body representing EU Member States, is responsible for ensuring harmonised safety standards for medicines authorised via national procedures across the EU.

As the CMDh position was adopted by majority vote, the $\mathrm{CMDh}$ position will now be sent to the European Commission, for the adoption of an EU-wide legally binding decision.

\section{References}

1. Perner A, Haase N, Guttormsen AB et al. (2012) Hydroxyethyl starch $130 / 0.42$ versus ringer's acetate in severe sepsis. N Engl J Med 367(2):124-34

2. Brunkhorst FM, Engel C, Bloos F et al. (2008) Intensive Insulin Therapy and Pentastarch Resuscitation in Severe Sepsis. N Engl J Med 358(2):125-39

3. Myburgh J, Finder S, Bellomo R et al. (2012) Hydroxyethyl starch or saline for fluid resuscitation in intensive care. N Engl J Med 367:1901-11
4. Annane D et al. CRISTAL: Colloids Compared to Crystalloids in Fluid Resuscitation of Critically III Patients: A Multinational Randomised Controlled Trial. NCT00318942. Available on: http://clinicaltrials.gov/ct2/show/NCT00318942

5. Siegemund M: Firstly presented at European Society of Anaesthesiology conference 2012. Basel Study for Evaluation of Starch $(130 ; 0.4)$ Infusion in Septic Patients: BaSES (130;0.4) Trial, listed at http://clinicaltrials.gov/show/NCT00273728

6. Rational Fluid Therapy in Germany (RaFTinG). Available on ClinicalTrials.gov (NCT01122277) last updated on 07 July 2011: http://clinicaltrials.gov/ ct2/show/NCT01122277?term =NCT01122277\&ra $\mathrm{nk}=1$ 